\title{
Severe necrotizing soft-tissue infection-associated mortality: Have a look at the computed tomography!
}

\author{
Sébastien Tanaka ${ }^{1,2^{*}+} \mathbb{0}$, Michael Thy ${ }^{1,3,4^{*}+}$, Ralph Khoury ${ }^{5}$, Alexy Tran-Dinh ${ }^{1,3,6}$, Antoine Khali $i^{3,5,7}$ and \\ Philippe Montravers ${ }^{1,3,7}$
}

Keywords: Necrotizing soft-tissue infection, Sepsis, Outcome, Intensive care unit, Computed tomography

Necrotizing soft-tissue infection (NSTI) is a life-threatening pathology, and the cornerstone treatment is based on early diagnosis, surgical source control and antimicrobial therapy [1]. Even if the diagnosis remains essentially clinical, computed tomography (CT) could be helpful in the diagnosis but remains controversial [2]. To date, there are no data screening the criteria for the place of initial CT-scan and patient outcomes. We aimed to evaluate the relationship between CT signs and the outcome of severe NSTI patients.

We retrospectively collected data for 100 patients with severe NSTI hospitalized in our intensive care unit (ICU) between 2009 and 2019 and whose diagnoses were surgically confirmed. Methods of this cohort have been previously published [3]. Patients who were clinically suspected of having NSTI benefited from urgent surgical exploration. CT was performed prior to surgery at the discretion of the clinician if the diagnosis of NSTI was uncertain or to assess the extent of the damage.

Four criteria for CT were evaluated according to previous guidelines $[4,5]$ :

- Gas in the soft tissues,

\footnotetext{
*Correspondence: sebastien.tanaka@aphp.fr

†Sébastien Tanaka and Michael Thy have contributed equally to the work

1 Assistance Publique - Hôpitaux de Paris (AP-HP), Department

of Anesthesiology and Critical Care Medicine, DMU PARABOL, Bichat-

Claude Bernard Hospital, 46 Rue Henri Huchard, 75018 Paris, France

Full list of author information is available at the end of the article
}

- Multiple fluid collections,

- Absence or heterogeneity of tissue enhancement by IV contrast.

- Significant inflammatory changes of the fascia and under.

The presence of these criteria was compared between survivors and nonsurvivors at day-90.

Of the 100 patients, 54 underwent CT before surgical exploration. Table 1 shows the comparison of general characteristics between the patients with and without $\mathrm{CT}$. The median (IQR) delay between $\mathrm{CT}$ and the surgical procedure was $5[2-20]$ hours. Table 2 shows the clinical and CT characteristics according to the survival or death status at day-90. In the multivariate analysis, in addition to the surface parameter (OR 1.15, 95\% CI 1.34, $p=$ 0.01 ), the criterion for inflammatory changes of the fascia was associated with mortality at day-90 (OR 8.09, 95\% CI $63.5, p=0.015)$. Inflammatory changes of the fascia parameter had a sensitivity of $60 \%$ (32-84), specificity of 92\% (79-98), positive predictive value of $75 \%$ (43-95) and negative predictive value of $86 \%$ (71-95).

In this study involving 100 severe ICU NSTI patients, we found that even if CT is not a diagnostic tool, it can

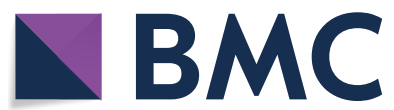

(c) The Author(s) 2022. Open Access This article is licensed under a Creative Commons Attribution 4.0 International License, which permits use, sharing, adaptation, distribution and reproduction in any medium or format, as long as you give appropriate credit to the original author(s) and the source, provide a link to the Creative Commons licence, and indicate if changes were made. The images or other third party material in this article are included in the article's Creative Commons licence, unless indicated otherwise in a credit line to the material. If material is not included in the article's Creative Commons licence and your intended use is not permitted by statutory regulation or exceeds the permitted use, you will need to obtain permission directly from the copyright holder. To view a copy of this licence, visit http://creativecommons.org/licenses/by/4.0/. The Creative Commons Public Domain Dedication waiver (http://creativeco mmons.org/publicdomain/zero/1.0/) applies to the data made available in this article, unless otherwise stated in a credit line to the data. 
Table 1 Overall baseline and outcome features of the study patients according to CT evaluation

\begin{tabular}{|c|c|c|c|c|}
\hline & Overall $n=100$ & No CT $n=46$ & $\mathrm{CT} n=54$ & $p$ value \\
\hline Age (years), median [IQR] & $58[50-68]$ & $57[48-68]$ & $59[53-68]$ & 0.31 \\
\hline Male sex, $n(\%)$ & $63(63)$ & $26(56.5)$ & $37(68.5)$ & 0.299 \\
\hline BMI $\left(\mathrm{kg} / \mathrm{m}^{2}\right)$, median [IQR] & $28[23-34]$ & $29[26-37]$ & 25 [22-32] & 0.059 \\
\hline Localization: limbs, $n$ (\%) & $52(52)$ & $35(76)$ & $17(31)$ & $<0.001$ \\
\hline Localization: pelvis, $n$ (\%) & $28(28)$ & $12(26)$ & $16(30)$ & 0.824 \\
\hline Localization: cephalic, n (\%) & $23(23)$ & $10(22)$ & $13(24)$ & 0.97 \\
\hline Localization: trunk, n (\%) & $13(13)$ & $1(2)$ & $12(22)$ & 0.008 \\
\hline Skin surface (\%), median [IQR] & $4.5[4.5-9]$ & $4.5[4.5-9.0]$ & $4.50[4.5-9.0]$ & 0.467 \\
\hline SAPS-II on admission, median [IQR] & $28[23-37]$ & $33[25-44]$ & $39[23-56]$ & 0.369 \\
\hline SOFA score on admission, median [IQR] & $5[3-6]$ & $4[1,7]$ & $4[1,9]$ & 0.721 \\
\hline LRINEC score on admission, median [IQR] & $2[1-4]$ & $3[2,5]$ & $3[1,5]$ & 0.709 \\
\hline Septic shock on admission, $n(\%)$ & $65(65)$ & $30(65)$ & $35(65)$ & 1 \\
\hline Day-1 cardiovascular failure (HD SOFA $\geq 1), n(\%)$ & $87(87)$ & $42(91)$ & $45(83)$ & 0.372 \\
\hline Day-1 respiratory failure (respiratory SOFA $\geq 1$ ), $n(\%)$ & $44(44)$ & $20(44)$ & $24(44)$ & 1 \\
\hline Day-1 renal failure (renal SOFA $\geq 1), n(\%)$ & $42(42)$ & $18(39)$ & $24(44)$ & 0.685 \\
\hline Charlson score on admission, median [IQR] & $4[3-7]$ & $3[2-5]$ & $5[3-7]$ & 0.008 \\
\hline \multicolumn{5}{|l|}{ Underlying medical conditions } \\
\hline Malignancy, n (\%) & $23(23)$ & $7(15)$ & $16(30)$ & 0.101 \\
\hline Obesity, n (\%) & $24(24)$ & $13(28)$ & $11(20)$ & 0.482 \\
\hline Diabetes mellitus, $n(\%)$ & $24(24)$ & $9(20)$ & $15(28)$ & 0.359 \\
\hline Coronary disease, $n(\%)$ & $20(20)$ & $5(11)$ & $15(28)$ & 0.044 \\
\hline Peripheral vascular disease, $n$ (\%) & $17(17)$ & $6(13)$ & $11(20)$ & 0.426 \\
\hline Alcohol use, $n(\%)$ & $20(20)$ & $8(17)$ & $12(22)$ & 0.621 \\
\hline Active smoking, $n(\%)$ & $54(54)$ & $24(52)$ & $30(55)$ & 0.841 \\
\hline Immunosuppression, n (\%) & $10(10)$ & $6(13)$ & $4(7)$ & 0.506 \\
\hline Renal replacement therapy during ICU stay, $n$ (\%) & $22(22)$ & $8(17)$ & $14(26)$ & 0.342 \\
\hline Vasoactive support during ICU stay, $n(\%)$ & $53(53)$ & $23(50)$ & $30(55)$ & 0.422 \\
\hline Mechanical ventilation during ICU stay, $n$ (\%) & $50(50)$ & $24(52)$ & $26(48)$ & 0.841 \\
\hline Limb amputation, $n$ (\%) & $13(13)$ & $8(17)$ & $5(9)$ & 0.234 \\
\hline Mortality at day-28, n (\%) & $18(18)$ & $7(15)$ & $11(20)$ & 0.448 \\
\hline Mortality at day-90, n (\%) & $23(23)$ & $8(17)$ & $15(28)$ & 0.243 \\
\hline
\end{tabular}

$B M I$ body mass index, HD hemodynamic, LRINEC laboratory risk indicators for necrotizing fasciitis score, SAPS-II simplified acute physiology score-II, SOFA sequential organ failure assessment

nevertheless provide some information on the patient's outcome. It is well established that the contribution of CT for an NSTI diagnosis is not only unreliable but can also delay the management of the patient, which is why in most cases, the diagnosis is made on the basis of clinical examinations and operative findings [4]. Our work partly confirms these elements since, when comparing patients who had a CT-scan versus those who did not, no difference according to the initial severity was found.

There are many diagnostic studies in which changes in the fascia (thickness, presence of edema, nonenhancement) can help in the diagnosis, but to our knowledge, our study is the first to evidence a link between fascia imaging and prognosis [6]. Nevertheless, as the fascia is a key structure in the spread of infection, our findings seem quite consistent.

Our study has limitations, including its monocentric design with only 100 NSTI patients and a long cohort period. Of course, almost half of the patients in the cohort did not have a CT-scan, which is an undeniable source of bias. A multicenter prospective larger cohort study has to be performed to confirm these results. 
Table 2 Relationship between the clinical and CT criteria and mortality at day-90

\begin{tabular}{|c|c|c|c|c|c|c|c|}
\hline & Univariate analysis & & & Multivariate & analy & & \\
\hline & Alive at day-90 $n=39$ & $\begin{array}{l}\text { Deceased } \\
\text { at day-90 } \\
n=15\end{array}$ & $p$ value & Odds ratio & $5 \%$ & $95 \% \mathrm{Cl}$ & $p$ value \\
\hline Age (years), median [IQR] & $58[51-67]$ & $66[56-68]$ & 0.203 & & & & \\
\hline Male sex, $n(\%)$ & $26(67)$ & $11(73)$ & 0.751 & & & & \\
\hline Obesity, n (\%) & $8(21)$ & $3(20)$ & 1 & & & & \\
\hline Diabetes mellitus, $n(\%)$ & $12(31)$ & $3(20)$ & 0.515 & & & & \\
\hline Localization: limbs, n (\%) & $10(26)$ & $7(47)$ & 0.192 & & & & \\
\hline Localization: pelvis, n (\%) & $10(26)$ & $6(40)$ & 0.333 & & & & \\
\hline Localization: cephalic, n (\%) & $12(31)$ & $1(7)$ & 0.083 & & & & \\
\hline Localization: trunk, n (\%) & $8(21)$ & $4(27)$ & 0.719 & & & & \\
\hline Skin surface (\%), median [IQR] & $5[5-9]$ & 18 [9-19] & $<0.001$ & 1.15 & 1.03 & 1.34 & 0.01 \\
\hline SOFA score on admission, median [IQR] & $4[1-7]$ & $8[3-10]$ & 0.053 & & & & \\
\hline SAPS-II on admission, median [IQR] & $33[21-52]$ & $47[40-56]$ & 0.023 & & & & \\
\hline LRINEC score on admission, median [IQR] & $2[1-5]$ & $4[3-6]$ & 0.096 & & & & \\
\hline Septic shock on admission, $n(\%)$ & $23(59)$ & $12(80)$ & 0.208 & & & & \\
\hline Delay of antibiotic initiation (days), median [IQR] & $1[0-4]$ & $1[0-3]$ & 0.82 & & & & \\
\hline CT characteristics & & & & & & & \\
\hline Gas in the soft tissues & $32(82)$ & $15(100)$ & 0.171 & & & & \\
\hline Multiple fluid collections & $6(15)$ & $8(53)$ & 0.012 & & & & \\
\hline Absence or heterogeneity of tissue enhancement & $33(85)$ & $15(100)$ & 0.17 & & & & \\
\hline Significant inflammatory changes of the fascia and under & $10(26)$ & $13(87)$ & $<0.001$ & 8.09 & 1.5 & 63.5 & 0.015 \\
\hline
\end{tabular}

Multivariate analysis was performed with the selection of the best model according to the lower AIC by a stepwise logistic regression

LRINEC laboratory risk indicators for necrotizing fasciitis score, SAPS-I/ simplified acute physiology score-II, SOFA sequential organ failure assessment

\section{Abbreviations}

CT: Computed tomography; ICU: Intensive care unit; NSTI: Necrotizing softtissue infection.

\section{Acknowledgements}

The authors would like to thank the medical and paramedical team of the Bichat Claude Bernard Surgical ICU, Paris, France.

\section{Authors' contributions}

ST, MT, AK and PM contributed to study concept and design. ST and MT performed statistical analysis. ST, MT, AK, RK, ATD and PM were involved in data analysis and interpretation. ST, ATD, AK and PM performed critical revision of the manuscript. All the authors read and approved the final manuscript.

\section{Funding}

None.

\section{Availability of data and materials}

The datasets analyzed during the current study are not publicly available but are available from the corresponding author on reasonable request.

\section{Declarations}

\section{Ethics approval and consent to participate}

This study was declared to the French Data Protection Authority (CNIL: 2096382) and was approved by the French Institutional Review Board (Comité d'Éthique de la Recherche en Anesthésie-Réanimation, IRB Number 00010254 2020-153). Due to the retrospective nature of this study, the need for signed informed consent was waived.

\section{Consent for publication}

Not applicable.

\section{Competing interests}

The authors declare that they have no competing interests.

\section{Author details}

${ }^{1}$ Assistance Publique - Hôpitaux de Paris (AP-HP), Department of Anesthesiology and Critical Care Medicine, DMU PARABOL, Bichat-Claude Bernard Hospital, 46 Rue Henri Huchard, 75018 Paris, France. ${ }^{2}$ French Institute of Health and Medical Research (INSERM), U1188 Diabetes Atherothrombosis Réunion Indian Ocean (DéTROI), CYROI Plateform, Réunion Island University, Saint-Denis de La Réunion, France. ${ }^{3}$ Université de Paris, Paris, France. ${ }^{4}$ EA 7323 - Pharmacology and Therapeutic Evaluation in Children and Pregnant Women, Paris Descartes University, Sorbonne Paris Cité University, Paris, France. ${ }^{5}$ Assistance Publique - Hôpitaux de Paris (AP-HP), Department of Radiology, DMU DREAM, Bichat-Claude Bernard Hospital, Paris, France. ${ }^{6}$ Laboratory for Vascular Translational Science, French Institute of Health and Medical Research (INSERM) U1 148, Paris, France. ${ }^{7}$ PHERE, Physiopathology and Epidemiology of Respiratory Diseases, French Institute of Health and Medical Research (INSERM) U1152, Paris, France.

Received: 14 December 2021 Accepted: 13 January 2022

Published online: 25 January 2022

\section{References}

1. Stevens DL, Bryant AE. Necrotizing soft-tissue infections. N Engl J Med. 2017:377(23):2253-65.

2. Zacharias N. Diagnosis of necrotizing soft tissue infections by computed tomography. Arch Surg. 2010;145(5):452. 
3. Tanaka S, Thy M, Tashk P, Ribeiro L, Lortat-Jacob B, Hermieu J-F, et al. Impact of prior antibiotic therapy on severe necrotizing soft-tissue infections in ICU patients: results from a French retrospective and observational study. Eur J Clin Microbiol Infect Dis Off Publ Eur Soc Clin Microbiol. 2021:41:109-17.

4. Sartelli M, Guirao X, Hardcastle TC, Kluger Y, Boermeester MA, Raşa K, et al. 2018 WSES/SIS-E consensus conference: recommendations for the management of skin and soft-tissue infections. World J Emerg Surg WJES. 2018:13:58.

5. Martinez M, Peponis T, Hage A, Yeh DD, Kaafarani HMA, Fagenholz PJ, et al. The role of computed tomography in the diagnosis of necrotizing soft tissue infections. World J Surg janv. 2018;42(1):82-7.

6. Bruls RJM, Kwee RM. CT in necrotizing soft tissue infection: diagnostic criteria and comparison with LRINEC score. Eur Radiol. 2021;31(11):8536-41.

\section{Publisher's Note}

Springer Nature remains neutral with regard to jurisdictional claims in published maps and institutional affiliations.

- fast, convenient online submission

- thorough peer review by experienced researchers in your field

- rapid publication on acceptance

- support for research data, including large and complex data types

- gold Open Access which fosters wider collaboration and increased citations

- maximum visibility for your research: over $100 \mathrm{M}$ website views per year

At BMC, research is always in progress.

Learn more biomedcentral.com/submissions 